\title{
Penerapan Pembelajaran Inquiry Terbimbing Untuk Meningkatkan Motivasi Dan Hasil Belajar IPA Pada Materi Gaya Dan Hukum Newton Terhadap Siswa SMP Negeri 2 Tanete Riaja Kabupaten Barru
}

\author{
Masniah \\ SMP Negeri 2 Tanete Riaja Kabupaten Barru \\ Email: masniah@gmail.com
}

\begin{abstract}
Abstrak: Penelitian ini bertujuan untuk mengetahui motivasi dan hasil belajar peserta didik kelas VIII-3 yang dibelajarkan dengan model pembelajaran Inquiry terbimbing pada materi gaya dan Hukum Newton. Penelitian ini adalah penelitian tindakan kelas yang terdiri dari dua siklus. Setiap siklus terdiri dari empat tahapan meliputi: perencanaan, tindakan, pengamatan, dan refleksi. Dalam penelitian ini terdapat dua jenis variabel yang dikaji yaitu: Variabel masalah yaitu Motivasi dan Hasil belajar IPA dan Variabel tindakan yaitu Penerapan pembelajaran Inquiry Terbimbing. Instrumen yang digunakan untuk mengukur dalam penelitian ini adalah instrumen angket motivasi dan lembar tes. analisis data yang digunakan adalah statistik deskriptif. Hasil penelitian ini menunjukkan bahwa penerapan pembelajaran Inquiry Terbimbing dapat meningkatkan motivasi dan hasil belajar IPA pada materi gaya dan Hukum Newton terhadap peserta didik kelas VIII-3 SMP Negeri 2 Tanete Riaja.
\end{abstract}

Kata kunci: Pembelajaran Inquiry Terbimbing; motivasi belajar; hasil belajar.

\begin{abstract}
This study aims to determine the motivation and learning outcomes of class VIII-3 students who are taught by a guided inquiry learning model on the material of Newton's Law and style. This research is a classroom action research consisting of two cycles. Each cycle consists of four stages including planning, acting, observing, and reflecting. In this study, there are two types of variables studied, namely: problem variables, namely motivation and science learning outcomes, and action variables, namely the application of guided inquiry learning. The instrument used to measure in this study was a motivation questionnaire instrument and a test sheet. The data analysis used was descriptive statistics. The results of this study indicate that the application of Guided Inquiry learning can improve motivation and science learning outcomes in Newtonian force and law material for class VIII-3 students of SMP Negeri 2 Tanete Riaja.
\end{abstract}

Keywords: Guided Inquiry Learning; learning motivation; learning outcomes. 


\section{PENDAHULUAN}

Salah satu masalah yang dihadapi dunia pendidikan saat ini adalah lemahnya proses pembelajaran. Pembelajaran dewasa ini masih didominasi oleh guru dan peserta didik kurang didorong untuk mengembangkan kemampuan berpikir peserta didik. Proses pembelajaran di kelas diarahkan kepada kemampuan anak untuk menghafal informasi tanpa dituntut untuk memahami informasi yang diingatnya itu untuk menghubungkanya dengan kehidupan seharihari. Akibatnya, ketika peserta didik lulus dari sekolah mereka pintar secara teoritis akan tetapi mereka miskin aplikasi. Kenyataan ini berlaku untuk semua mata pelajaran. Menanggapi hal tersebut perlu adanya perbaikan dalam sistem pendidikan terkhusus terhadap proses pembelajaran sebagai urat nadi dan proses utama dalam pendidikan.

IPA adalah salah satu mata pelajaran penting di sekolah. IPA adalah ilmu yang mempelajari tentang mahluk hidup mulai dari yang sangat kecil hingga tingkat tinggi, termasuk segala proses yang berlansung dalam tubuh makhluk hidup dan yang mendukung kelangsungan hidupnya. Hal inilah yang sering membuat mata pelajaran IPA abstrak bagi para peserta didik yang nantinya akan berdampak pula pada hasil belajar yang dicapai peserta didik. Berdasarkan hasil observasi penulis di SMP Negeri 2 Tanete Riaja, diperoleh fakta bahwa beberapa peserta didik kesulitan memahami dan menguasai beberapa pokok bahasan dalam pembelajaran IPA yang mengakibatkan rendahnya motivasi dan hasil belajar peserta didik, sehingga kriteria ketuntasan minimal (KKM) yang telah ditetapkan, yaitu 75 . Persentase peserta didik yang mencapai KKM hanya mencapai $65 \%$.

Usaha guru untuk membelajarkan peserta didik merupakan suatu bagian yang sangat penting dalam mencapai keberhasilan dan tujuan pembelajaran IPA yang telah direncanakan. Oleh karena itu, pemilihan berbagai metode, strategi, pendekatan, serta teknik pembelajaran merupakan suatu hal yang utama. Salah satu tujuan dalam penggunaan model pembelajaran adalah untuk meningkatkan kemampuan peserta didik selama belajar sehingga diharapkan adanya perubahan pola pikir yaitu dari mengingat kearah berpikir dan pemahaman dalam pembelajaran. Guru berusaha mengalihkan cara pembelajaran dengan metode ceramah/konvensional seperti yang dominan terlihat pada model pembelajaran langsung ke model pembelajaran Inkuiri Terbimbing dalam meningkatkan motivasi belajar peserta didik dan hasil belajar peserta didik. Untuk dapat memenuhi tuntutan dan tujuan pengajaran maka guru harus dapat memberikan kesempatan kepada peserta didik untuk mengalami sendiri atau melakukan sendiri, mengikuti proses, mengamati suatu objek menganalisis, membuktikan, dan menarik kesimpulan sendiri tentang suatu objek, keadaan atau suatu proses dalam lingkup materi pelajaran IPA. Guru harus mampu menciptakan suatu pembelajaran yang sekaligus mengubah pola lama (pembelajaran berorientasi teacher-centered). Salah satu model pembelajaran yang peneliti coba dikembangkan dan diyakini dapat meningkatkan motivasi dan hasil belajar peserta didik adalah model pembelajaran Inkuiri terbimbing dengan asumsi bahwa peserta didik akan melakukan pembelajaran secara bermakna karena mereka dilibatkan secara langsung dan menyaksikan secara langsung materi yang mereka pelajari dengan media yang ditampilkan didepan kelas. Selain itu, motivasi adalah salah satu faktor yang mempengaruhi hasil belajar peserta didik. Diketahui bahwa bukan materi pelajaran yang membuat pembelajaran lebih berharga dari pada yang lain, melainkan motivasi dalam melaksanakan pembelajaran itu.

Sehubungan dengan hal tersebut, diperlukan suatu model pembelajaran yang dapat digunakan oleh para guru untuk melaksanakan kegiatan pembelajaran dengan baik sehingga dapat membantu meningkatkan motivasi dan hasil belajar peserta didik, yang tentunya relevan dengan perkembangan teori pembelajaran terkini, yakni konstruktivistik.

SMP Negeri 2 Tanete Riaja memiliki sarana dan prasarana yang mampu mendukung terlaksananya pembelajaran Inquiry terbimbing untuk meningkatkan motivasi belajar dan hasil belajar peserta didik. Sarana dan prasarana tersebut yaitu memiliki laboratorium IPA, memiliki perpustakaan dengan koleksi bacaan yang memadai, 
memiliki laboratorium komputer, tersedia ruang kelas yang sesuai dengan rombongan belajar serta memiliki kultur sekolah yang mendukung.

$$
\text { Menurut Hanafiah (2009) }
$$

pembelajaran inkuiri merupakan suatu rangkaian kegiatan pembelajaran yang melibatkan secara maksimal seluruh kemampuan peserta didik pada proses berpikir secara kritis dan analitis untuk mencari dan menemukan sendiri jawaban suatu masalah yang dipertanyakan. Tujuan utama model inquiry adalah mengembangkan kemampuan berpikir, sehingga model ini selain berorientasi pada hasil belajar, juga berorientasi pada proses belajar. Oleh karena itu kriteria keberhasilan dari proses pembelajaran dengan menggunakan Inkuiri bukan ditentukan oleh sejauh mana peserta didik menguasai materi pelajaran, tetapi sejauh mana peserta didik beraktivitas mencari dan menemukan sendiri.

Ada beberapa hal yang menjadi ciri utama pembelajaran Inkuiri menurut Sanjaya (2010) adalah sebagai berikut:

1. Inkuiri menekankan kepada aktifitas peserta didik secara maksimal untuk mencari dan menemukan, artinya model Inkuiri menempatkan peserta didik sebagai subjek belajar. Dalam proses pembelajaran, peserta didik tidak hanya berperan sebagai penerima pelajaran melalui penjelasan guru secara verbal, tetapi mereka berperan untuk menemukan sendiri inti dari materi pelajaran itu sendiri.

2. Seluruh aktifitas peserta didik diarahkan untuk mencari dan menemukan jawaban sendiri dari sesuatu yang dipertanyakan, sehingga diarahkan dapat menumbuhkan sikap percaya diri (self confidence). Dengan demikian, model pembelajaran Inkuiri menempatkan guru bukan sebagai subjek belajar, akan tetapi sebagai fasilitator dan motivator belajar peserta didik.

3. Inkuiri mengembangkan kemampuan berpikir secara sistematis, logis dan kritis, atau mengembangkan kemampuan intelektual sebagai bagian dari proses mental. Dengan demikian, dalam model pembelajaran Inkuiri peserta didik tidak hanya dituntut agar menguasai materi pelajaran, akan tetapi bagaimana mereka dapat menggunakan potensi yang dimilikinya.

Model pembelajaran inquiry menurut

Hanafiah (2009), terbagi tiga jenis berdasarkan besarnya intervensi guru terhadap peserta didik atau besarnya bimbingan yang diberikan oleh guru kepada peserta didiknya. Ketiga jenis pembelajaran inquiry sebagai berikut: model pembelajaran inkuiri terbimbing (guide inkuiri model), model pembelajaran inquiry bebas (free inquiry model), dan inquiry bebas termodifikasi (modified free inquiry model).

\section{Model pembelajaran inkuiri terbimbing}

Model pembelajaran inkuiri terbimbing melatih kemampuan peserta didik dalam meneliti, menjelaskan fenomena, dan memecahkan masalah secara ilmiah, hal ini akan meningkatkan keterlibatan peserta didik secara maksimal dalam proses kegiatan belajar yang meliputi kegiatan mental, intelektual dan sosial emosional. Selain itu juga dapat mengembangkan sikap percaya pada diri sendiri (self belief) pada diri peserta didik. Pada pembelajaran inquiry terbimbing peserta didik dibimbing untuk menemukan konsep sendiri namun tetap terbimbing.

Model pembelajaran inquiry terbimbing dikembangkan oleh seorang tokoh yang bernama Suchman (Uno, 2009), suchman menyatakan bahwa anak-anak adalah individu yang penuh rasa ingin tahu akan segala sesuatu. Oleh karena itu proses ilmiah dapat diajarkan langsung kepada mereka. Sementara Gulo (2008) menyatakan bahwa inquiry dalam bahasa inggris berarti pertanyaan atau pemeriksaan, penyelidikan. Pertanyaan merupakan inti dari pembelajaran berbasis inquiry. Pertanyaan dapat menuntun untuk melakukan penyelidikan sebagai usaha peserta didik dalam memahami materi pembelajaran. Model pembelajaran inquiry sebagai suatu rangkaian kegiatan belajar yang melibatkan secara maksimal seluruh kemampuan peserta didik untuk mencari dan menyelidiki secara sistematis, kritis, logis, analitis, sehingga mereka dapat merumuskan sendiri penemuanya dengan penuh percaya diri.

Menurut Suparno (2007) dalam Kemendikbud (2014), Inquiry terbimbing atau terarah adalah inquiry yang banyak 
dicampuri oleh guru. Guru banyak mengarahkan, memberikan petunjuk baik lewat prosedur yang lengkap dan pertanyaanpertanyaan pengarahan selama prose inkuiri. Pada inkuiri terbimbing peran guru tidak berarti pasif, tetapi aktif mengarahkan peserta didik yang memerlukan bimbingan dalam menyusun rancangan dan pelaksanaan eksperimen.

Berdasarkan uraian diatas dapat disimpulkan bahwa pembelajaran inquiry terbimbing adalah proses belajar yang menekankan kemampuan peserta didik dalam mencari tahu segala fenomena yang terjadi. Hal ini dilakukan dengan melakukan serangkaian percobaan dengan sebelumnya membuat hipotesis hingga berujung pada pemecahan masalah. Penelitian diharapkan dapat dijadikan sebagai alternatif, strategi pembelajaran untuk proses pembelajaran yang lebih memotivasi peserta didik agar lebih aktif dalam kegiatan pembelajaran sehingga meningkatkan hasil belajar peserta didik.

Pendekatan Inkuiri terbimbing merupakan salah satu pendekatan pembelajaran yang banyak melibatkan peserta didik dalam kegiatan belajar mengajar, dan memerlukan proses mental untuk menemukan konsep. Guru dalam hal ini berperan sebagai fasilitator dan membimbing peserta didik saat diperlukan, peserta didik dimotivasi untuk berpikir sendiri sehingga dapat menemukan prinsip umum berdasarkan bahan dan data yang telah disediakan. Seberapa jauh peserta didik memperoleh bimbingan tergantunh pada kemampuanya dan materi yang sedang dipelajari, pembelajaran peserta didik harus memungkinkan proses mental, seperti mengamati, mengklasifikasi, mengukur, mengumpulkan hasil pengamatan, dan menyimpulkan.

Markaban (2006) menyatakan beberapa langkah yang dapat ditempuh oleh seorang guru dalam pelaksanaan Inkuiri terbimbing adalah sebagai berikut.

1. Merumuskan masalah yang akan diberikan kepada peserta didik dengan data secukupnya. Perumusannya harus jelas, hindari pernyataan yang menimbulkan salah tafsir, sehingga yang ditempuh peserta didik tidak salah arah.
2. Berdasarkan data yang diberikan guru, peserta didik menyusun, memproses, mengorganisir dan menganalisis data tersebut. Dalam hal ini, bimbingan guru dapat diberikan sejauh yang diperlukan saja. Bimbingan ini sebaiknya dapat mengarahkan peserta didik untuk melangkah kearah yang hendak dituju melalui pertanyaan-pertanyaan atau dalam LKS.

3. Peserta didik menyusun hipotesa dari hasil yang dilakukan.

4. Bila dipandang perlu, hipotesa yang telah dibuat oleh peserta didik diperiksa oleh guru. Hal ini penting untuk meyakingkan kebenaran hipotesa peserta didik sehingga tidak salah arah.

5. Apabila telah yakin dengan kebenaran hipotesa tersebut, maka verbalisasi hipotesa sebaiknya diserahkan kepada peserta didik untuk menyusunnya.

6. Setelah peserta didik menemukan apa yang hendak dicapai, sebaiknya guru memberikan soal latihan untuk memeriksa apakah hasil penemuan itu benar.

Keunggulan model pembelajaran Inkuiri menurut Sanjaya (2010) adalah sebagai berikut.

1. Menekankan kepada pengembangan aspek kognitif psikomotor secara seimbang, sehingga pembelajaran melalui model ini dianggap lebih bermakna.

2. Memberikan ruang kepada peserta didik untuk belajar sesuai dengan gaya belajar mereka.

3. Model pembelajaran Inkuiri sesuai dengan perkembangan psikologi belajar modern yang menganggap belajar adalah proses perubahan tingkah laku berkat adanya pengalaman.

4. Dapat melayani kebutuhan peserta didik yang memiliki kemampuan diatas ratarata, artinya, peserta didik yang memiliki kemampuan belajar bagus tidak akan terhambat oleh peserta didik yang mengalami hambatan dalam belajar.

Kelemahan model pembelajaran Inkuiri menurut Sanjaya (2010) antara lain sebagai berikut.

1. Jika menggunakan model pembelajaran ini, maka akan sulit mengontrol kegiatan dan keberhasilan peserta didik. 
2. Strategi ini sulit dalam merencanakan pembelajaran oleh karena terbentur dengan kebiasaan peserta didik dalam belajar.

3. Kadang-kadang dalam mengimplemen tasikan model pembelejaran inkuiri, memerlukan waktu yang panjang sehingga sering guru sulit menyesuaikannya dengan waktu yang telah ditentukan.

4. Selama kriteria keberhasilan belajar ditentukan oleh kemampuan peserta didik menguasai materi pelajaran, maka model pembelajaran ini sulit diimplementasikan oleh setiap guru.

Pada proses belajar peserta didik memerlukan waktu untuk menggunakan daya otaknya untuk berpikir dan memperoleh pengertian tentang konsep, prinsip dan teknik menyelidiki. Kegiatan-kegiatan yang dapat meningkatkan teknik Inkuiri menurut Roestiyah (2008) adalah sebagai berikut. Membimbing kegiatan laboratorium, modifikasi Inkuiri, kebebasan Inkuiri, Inkuiri pendekatan peranan, mengundang ke dalam Inkuiri, teka-teki bergambar, dan kejelasan nilai-nilai.

Kondisi-kondisi yang mendukung terlaksananya teknik Inkuiri dengan baik menurut Roestiyah (2008) yaitu (1) Kondisi yang fleksibel, bebas untuk berinteraksi, (2) Kondisi lingkungan yang response, (3) Kondisi yang memudahkan untuk memusatkan, dan (4) Kondisi yang bebas dari tekanan.

\section{Motivasi belajar}

Istilah motivasi berasal dari kata motif yang dapat diartikan sebagai kekuatan yang terdapat dalam diri individu, yang menyebabkan individidu tersebut bertindak atau berbuat, Uno (2006). Sejalan yang dikemukakan oleh Sarta dalam bukunya Psichologi Understanding of Human Behavior. Motif adalah suatu pernyataan yang kompleks dalam suatu organisme yang mengarahkan tingkah laku atau perbuatan ke suatu tujuan atau peransang Purwanto (2002). Dengan demikian motivasi merupakan dorongan yang terdapat dalam diri seseorang untuk berusaha mengadakan perubahan tingkah laku yang lebih baik dalam memenuhi kebutuhannya, Uno (2006:).

Pada kegiatan belajar, motivasi dapat dikatakan keseluruhan daya penggerak dalam diri peserta didik yang menimbulkan kegiatan belajar yang menjamin kelangsungan dari kegiatan belajar, sehingga tujuan yang dikehendaki oleh subyek belajar itu dapat tercapai. Motivasi belajar adalah merupakan faktor psikis yang bersifat non intelektual, perananya yang khas adalah dalam hal menimbulkan gairah merasa senang dan semangat untuk belajar.

Motivasi pada dasarnya dapat membantu dalam memahami dan menjelaskan perilaku individu, termasuk perilaku individu yang sedang belajar. Uno (2010) mengungkapkan beberapa peranan penting dari motivasi dalam belajar dan pembelajaran, sebagai berikut.

1. Peranan motivasi dalam menentukan penguatan belajar

Motivasi dapat berperan dalam penguatan belajar apabila seorang anak yang belajar dihadapkan pada suatu masalah yang memerlukan pemecahan, dan hanya dapat dipecahkan berkat bantuan hal-hal yang pernah dilaluinya.

2. Peranan Motivasi Dalam Memperjelas Tujuan Belajar

Peranan motivasi dalam memperjelas tujuan belajar erat kaitanya dengan kemaknaan belajar. Anak akan tertarik untuk belajar sesuatu, jika yang dipelajari itu setidaknya sudah dapat diketahui atau dinikmati mamfaatnya bagi anak.

3. Motivasi Menentukan Ketekunan Belajar Seorang anak yang telah termotivasi untuk belajar sesuatu, akan berusaha mempelajarinya dengan baik dan tekun, dengan harapan memperoleh hasil yang baik. Dalam hal itu, tampak bahwa motivasi untuk belajar menyebabkan seseorang tekun belajar. Sebaliknya, apabila seseorang kurang atau tidak memiliki motivasi untuk belajar, maka dia tidak tahan lama belajar. Dia mudah tergoda untuk mengerjakan hal yang lain dan bukan belajar. Itu berarti motivasi sangat berpengaruh terhadap ketahanan dan ketekunan belajar.

Motivasi belajar dapat timbul karena faktor instrinsik, berupa hasrat dan keinginan berhasil dan dorongan kebutuhan belajar, harapan akan cita-cita. Sedangkan faktor ekstrensiknya adalah adanya penghargaan, 
lingkungan belajar yang kondusif, dan kegiatan belajar yang menarik. Kedua faktor tersebut di sebabkan oleh rangsangan tertentu, sehingga seseorang berkeinginan untuk melakukan aktifitas belajar yang lebih giat dan semangat.

Menurut Am (2011) bahwa ada beberapa bentuk dan cara untuk menumbuhkan motivasi dalam kegiatan belajar di sekolah, adalah sebagai berikut.

1. Memberi angka, angka dalam hal ini sebagai simbol dari nilai kegiatan belajarnya. Banyak peserta didik yang belajar, yang utama untuk mencapai nilai yang baik. Biasanya peserta didik mengejar nilai ulangan atau nilai rapor yang baik. Angka atau nilai yang baik bagi peserta didik merupakan motivasi yang sangat kuat.

2. Hadiah, dapat juga dikatakan sebagai motivasi, tetapi tidak selalu demikian. Karena hadiah untuk suatu pekerjaan, mungkin tidak akan menarik bagi seseorang yang tidak senang dan tidak berbakat untuk sesuatu pekerjaan tersebut.

3. Persaingan atau kompetisi, persaingan atau kompetisi dapat digunakan sebagai alat motivasi untuk mendorong belajar peserta didik, baik persaingan individual maupun persaingan kelompok dapat meningkatkan prestasi belajar peserta didik.

4. Keterlibatan diri, menumbuhkan kesadaran kepada peserta didik agar merasakan pentingnya tugas dan menerimanya sebagai tantangan sehingga bekerja keras dengan mempertaruhkan harga diri, adalah sebagai salah satu bentuk motivasi yang cukup penting. Seseorang akan berusaha dengan segenap tenaga untuk mencapai prestasi yang baik dengan menjaga harga dirinya. Penyelesaian tugas-tugas dengan baik adalah simbol kebanggaan dan harga diri, begitu juga untuk peserta didik. Para peserta didik akan belajar dengan keras bisa jadi karena harga dirinya.

5. Memberi ulangan, peserta didik akan menjadi giat belajar kalau mengetahui akan ada ulangan. Oleh karena itu, memberi ulangan ini juga merupakan sarana motivasi.

6. Mengetahui hasil, dengan mengetahui grafik hasil belajar meningkat, maka ada motivasi pada diri peserta didik untuk terus belajar, dengan harapan hasilnya akan terus meningkat.

7. Pujian, pujian adalah bentuk reinforcement yang positif dan merupakan motivasi yang baik. Supaya pujian merupakan motivasi, pemberianya harus tepat. Dengan pujian yang tepat akan memupuk suasana yang menyenangkan dan meningkatkan gairah belajar.

8. Hukuman, hukuman sebagai reinforcement yang negatif tetapi kalau diberikan secara tepat bisa menjadi alat motivasi.

9. Hasrat untuk belajar, hasrat untuk belajar berarti ada unsur kesengajaan, ada maksud untuk belajar. Hal ini akan lebih baik, bila dibandingkan segala sesuatu tanpa maksud. Pada diri anak didik memang ada motivasi untuk belajar, sehingga hasilnya akan lebih baik. Cara menumbuhkan hasrat untuk belajar adalah guru memberi tugas, sehingga ada maksud peserta didik untuk mau belajar dan guru memberikan imformasi kepada peserta didik bahwa belajar dapat memberikan ilmu dan pengetahuan.

10.Minat, motivasi muncul karena adanya kebutuhan, begitu juga dengan minat. Sehingga minat merupakan alat motivasi. Minat dapat dibangkitkan dengan cara sebagai berikut, a) Membangkitkan adanya suatu kebutuhan, b) Menghubungkan dengan persoalan pengalaman yang lampau, c) Memberi kesempatan untuk mendapatkan hasil yang baik, dan d) Menggunakan berbagai macam metode mengajar.

11.Tujuan yang diakui, rumusan tujuan yang diterima oleh peserta didik, merupakan alat motivasi yang sangat penting. Dengan memahami tujuan yang harus dicapai, maka akan timbul gairah untuk terus belajar.

\section{Hasil Belajar}

Hasil belajar di tandai dengan adanya perubahan perilaku yang terjadi pada diri seseorang yang melakukanya. Hasil belajar IPA merupakan suatu puncak dari proses belajar, hasil belajar tersebut dapat terjadi karena adanya evaluasi yang dilakukan oleh guru. Jika dikaitkan dengan belajar IPA maka 
hasil belajar IPA merupakan suatu hasil yang diperoleh peserta didik dalam menekuni dan mempelajari IPA.

Menurut Slameto (2003), hasil belajar dipengaruhi oleh beberapa faktor, baik faktor dari dalam (faktor internal) maupun dari luar (faktor eksternal). Faktor internal adalah faktor jasmaniah, fsikologis, dan faktor kelelahan (misalnya, intelegensi, perhatian, minat, bakat, motivasi, kematangan, dan kesiapan), sedangkan yang termasuk faktor eksternal adalah faktor keluarga, faktor sekolah, dan faktor masyarakat (misalnya guru, kurikulum, dan model pembelajaran). Bloom dalam Sopah (2000), mengemukakan tiga faktor utama yang memengaruhi hasil belajar, yaitu kemampuan kognitif, motivasi berprestasi, dan kualitas pembelajaran.

Indikator hasil belajar merupakan target pencapaian kompetensi secara operasional dari kompetensi dasar dan standar kompetensi. Menurut Sofyan (2006) ada tiga aspek kompetensi yang harus dinilai untuk mengetahui seberapa besar capaian kompetensi tersebut, sebagai berikut:

1. Hasil belajar penguasaan materi akademik (kognitif)

2. Hasil belajar yang bersifat proses normatif (Afektif)

3. Hasil belajar aplikatif (Psikomotor)

\section{Hipotesis Penelitian}

Adapun hipotesis dalam penelitian ini adalah sebagai berikut:

1. Penerapan pembelajaran inquiry terbimbing akan meningkatkan motivasi belajar peserta didik kelas VIII-3 SMP Negeri 2 Tanete Riaja.

2. Penerapan pembelajaran inquiry terbimbing akan meningkatkan hasil belajar IPA peserta didik kelas VIII-3 SMP Negeri 2 Tanete Riaja.

\section{METODE PENELITIAN}

Penelitian ini adalah penelitian tindakan kelas yang bertujuan untuk mendapatkan informasi tentang peningkatan motivasi dan hasil belajar peserta didik kelas VIII-3 SMP Negeri 2 Tanete Riaja Kabupaten Barru. Jumlah subjek penelitian sebanyak 23 peserta didik, dimana terdapat 9 orang lakilaki dan 14 orang perempuan. Dalam penelitian ini pula melibatkan satu orang guru sebagai pengamat.

Pelaksanaan penelitian ini dirancang dan direncanakan secara bersiklus yakni Siklus I, Siklus II dan seterusnya. Setiap siklus terdiri dari empat tahapan atau langkah pelaksanaan tindakan yang disertai dengan beberapa perbaikan dan penambahan sesuai dengan kenyataan yang ditemukan. Tahapantahapan pada masing-masing siklus meliputi: perencanaan, tindakan, pengamatan, dan refleksi.

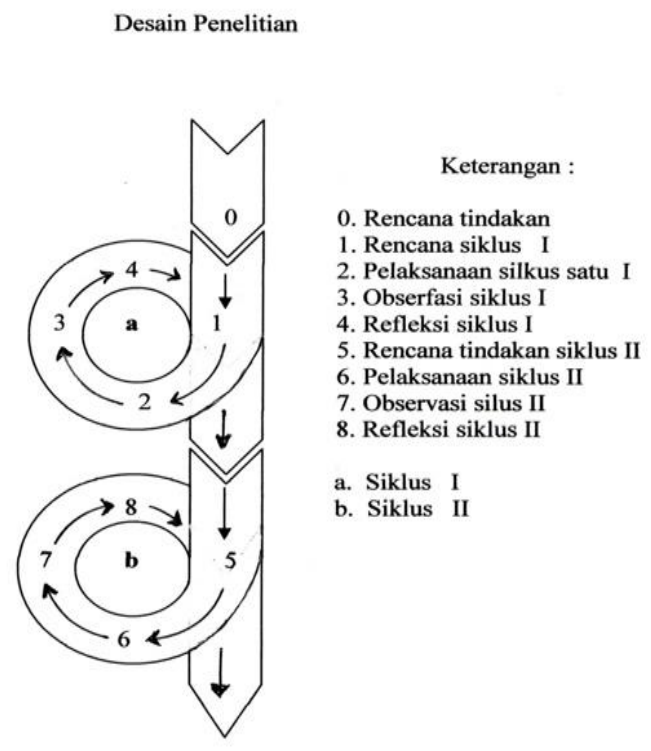

Gambar 1. Desain Penelitian

Dalam penelitian ini terdapat dua jenis variabel yang dikaji yaitu: Variabel masalah yaitu Motivasi dan Hasil belajar IPA dan Variabel tindakan yaitu Penerapan pembelajaran Inquiry Terbimbing. Definisi Operasional Variabel adalah sebagai berikut:

a. Motivasi adalah sesuatu yang menyebabkan terjadinya suatu perubahan dalam diri individu yang mempengaruhi gejala kejiwaan, perasaan, dan emosi untuk melakukan sesuatu yang didorong oleh adanya tujuan, kebutuhan atau keinginan.

b. Hasil belajar peserta didik adalah tingkat penguasaan yang dicapai peserta didik setelah mengikuti proses pembelajaran IPA sesuai dengan tujuan yang ditetapkan dan terukur melalui tes hasil belajar. 
c. Model pembelajaran Inkuiri terbimbing merupakan model pembelajaran yang diterapkan oleh peneliti di kelas, yang terdiri dari 5 langkah, yaitu 1) pertama, menyajikan pertanyaan atau masalah, 2) kedua, membuat hipotesis, 3) ketiga, mengumpulkan data, 4) keempat, menguji hipotesis untuk memperoleh informasi, dan 5) kelima, menarik kesimpulan.

Instrumen yang digunakan untuk mengukur dalam penelitian ini adalah: 1) instrumen angket motivasi digunakan untuk memperoleh data motivasi belajar peserta didik Angket motivasi ini terdiri dari 20 item pernyataan yang dikembangkan berdasarkan indikator yang meliputi: (1) ketekunan dalam belajar, (2) Ulet dalam menghadapi kesulitan,(3) Adanya harapan dan cita-cita masa depan (4) Adanya penghargaan dalam belajar (5) mandiri dalam belajar, (6) Adanya kegiatan yang menarik dalam belajar, dan (7) Adanya lingkungan yang kondunsif sehingga memungkinkan seorang peserta didik dapat belajar dengan baik.; 2) Tes digunakan untuk memperoleh data hasil belajar peserta didik. Tes ini dilakukan dua kali pada setiap perlakuan yakni pada saat akhir setiap siklus. Lembar tes dibuat berdasarkan pada standar kompetensi dan kompetensi dasar serta tujuan pembelajaran. Instrumen yang digunakan dalam bentuk tes uraian.

Analisis statistik deskriptif merupakan analisis data untuk mendeskriptifkan atau menggambarkan data motivasi dan hasil belajar peserta didik yang telah terkumpul melalui gambaran karakteristik distribusi nilai pencapaian motivasi dan hasil belajar peserta didik. Analisis deskriptif bertujuan untuk mendeskripsikan motivasi dan hasil belajar yang diperoleh peserta didik selama pembelajaran.

Data motivasi belajar peserta didik diperoleh melalui langkah-langkah sebagai berikut:

1. Menghitung jumlah skor dari setiap motivasi yang diamati.

2. Menghitung presentase motivasi dengan membagi jumlah skor motivasi perolehan peserta didik dengan jumlah skor maksimal.
3. Menghitung skor rata-rata dengan membagi jumlah perolehan dengan banyaknya item pada angket motivasi pada setiap indikator.

4. Dinyatakan dengan rumus:

skor motivasi $\frac{\text { skor perolehan siswa }}{\text { skor maksimal }}$ x 100\%

Analisis dilakukan menggunakan model skala likert. Peserta didik dikatakan mempunyai motivasi belajar yang baik, jika skor peserta didik berada pada skor 68 atau lebih, selanjutnya nilai motivasi dikelompokkan berdasarkan tabel berikut.

Tabel 1. Kategori Motivasi Belajar Peserta didik

\begin{tabular}{lll}
\hline No & Nilai & Kategori \\
\hline 1 & $84 \leq \mathrm{M}<100$ & Sangat Tinggi \\
\hline 2 & $68 \leq \mathrm{M}<84$ & Tinggi \\
\hline 3 & $52 \leq \mathrm{M}<68$ & Baik \\
\hline 4 & $36 \leq \mathrm{M}<52$ & Cukup \\
\hline 5 & $20 \leq \mathrm{M}<36$ & Rendah \\
\hline
\end{tabular}

Sumber : Modifikasi dari Sugiyono, (2010)

Analisis hasil belajar secara umum diarahkan pada pencapaian hasil belajar secara individual dan klasikal. Peserta didik dikatakan berhasil dalam belajar jika memperoleh nilai minimal $\geq 75$ berdasarkan KKM yang telah ditetapkan. Secara klasikal pembelajaran dikatakan berhasil jika minimal $85 \%$ peserta didik mencapai skor minimal 75 hasil belajar peserta didik selanjutnya dibandingkan dengan mengelompokkan hasil belajar (Depdiknas, 2003), dapat dilihat pada tabel 2.

Tabel 2. Kategori Hasil Belajar Peserta didik

\begin{tabular}{cc} 
Interval Nilai & Kategori \\
\hline $88-100$ & Sangat Baik \\
$63-87$ & Baik \\
$39-62$ & Cukup \\
$00-38$ & Kurang \\
\hline
\end{tabular}

Sumber: Permendikbud Nomor 104, (2014)

\section{HASIL DAN PEMBAHASAN}

\section{Motivasi Belajar}

Motivasi belajar peserta didik selama diterapkan pembelajaran Inquiry Terbimbing secara umum terjadi peningkatan setelah dilakukan beberapa tindakan pada setiap 
Vol,5. No,1. Tahun 2021

siklusnya. Motivasi belajar peserta didik selengkapnya diperlihatkan pada tabel 3 , tabel 4 dan gambar 2 berikut ini.

Tabel 3. Angket Motivasi Belajar Kelas VIII3 Siklus I

\begin{tabular}{cccc}
\hline \multicolumn{4}{c}{ Kategori } \\
No & $\begin{array}{c}\text { Motivasi } \\
\text { Belajar }\end{array}$ & $\begin{array}{c}\text { Peserta } \\
\text { Didik }\end{array}$ & $\begin{array}{c}\text { Persentase } \\
\text { Motivasi } \\
\text { Belajar } \\
(\%)\end{array}$ \\
\hline 1 & $\begin{array}{c}\text { Sangat } \\
\text { Tinggi }\end{array}$ & 0 & 0 \\
\hline 2 & Tinggi & 7 & 30 \\
\hline 3 & Baik & 16 & 70 \\
\hline 4 & Cukup & 0 & 0 \\
\hline
\end{tabular}

\begin{tabular}{llll}
\hline 5 & Rendah & 0 & 0 \\
\hline
\end{tabular}

Tabel 4. Angket Motivasi Belajar Kelas VIII3 Siklus II

\begin{tabular}{cccc}
\hline No & $\begin{array}{c}\text { Kategori } \\
\text { Motivasi } \\
\text { Belajar }\end{array}$ & $\begin{array}{c}\text { Banyaknya } \\
\text { Peserta } \\
\text { Didik }\end{array}$ & $\begin{array}{c}\text { Persentase } \\
\text { Motivasi } \\
\text { Belajar } \\
(\%)\end{array}$ \\
\hline 1 & $\begin{array}{c}\text { Sangat } \\
\text { Tinggi }\end{array}$ & 0 & 0 \\
\hline 2 & Tinggi & 23 & 100 \\
\hline 3 & Baik & 0 & 0 \\
\hline 4 & Cukup & 0 & 0 \\
\hline 5 & Rendah & 0 & 0 \\
\hline
\end{tabular}

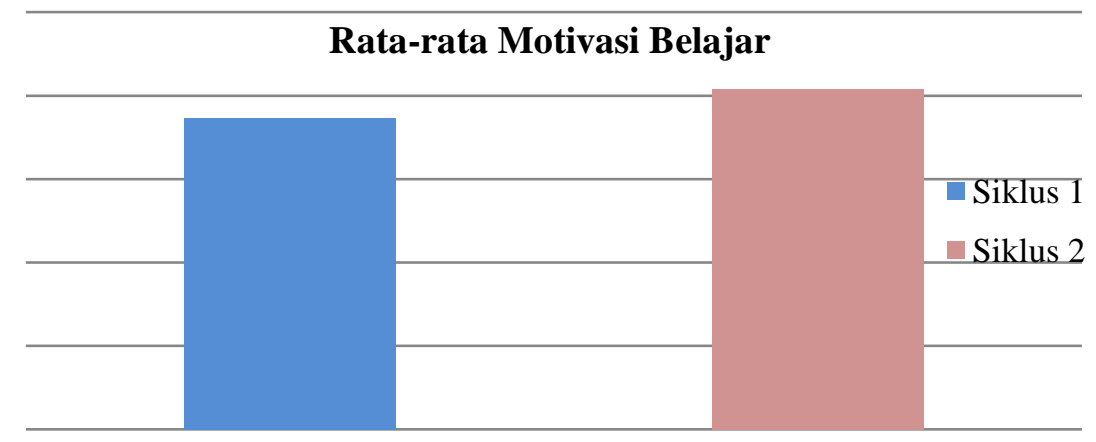

Gambar 2. Rata-rata motivasi belajar peserta didik

Pada gambar 2 menunjukkan bahwa pada siklus I rata-rata skor angket motivasi mencapai 74,62. Setelah dilakukan tindakan perbaikan untuk meningkatkan motivasi belajar peserta didik pada siklus II dengan: (1) memberikan motivasi kepada anggotaanggota kelompok agar lebih aktif lagi mengikuti setiap kegiatan dalam pembelajaran Inquiry Terbimbing, (2) lebih intensif membimbing kelompok yang mengalami kesulitan dalam pembelajaran, (3) melakukan pengelompokan ulang berdasarkan hasil tes hasil belajar dan mengatur letak masing-masing kelompok pada pertemuan di siklus II, (3) mengarahkan kepada setiap anggota kelompok yang telah memahami materi pelajaran untuk lebih aktif membimbing anggota kelompok yang mengalami kesulitan dalam pembelajaran. Pada akhir siklus II rata-rata skor motivasi belajar peserta didik kelas VIII-3 mencapai 81,61 .

\section{Hasil Belajar}

Dalam penelitian ini, salah satu aspek yang memengaruhi keberhasilan penelitian adalah hasil belajar peserta didik yang teramati melalui tes hasil belajar pada siklus I, dan hasil tes hasil belajar pada siklus II. Perkembangan hasil belajar peserta didik selama penelitian dapat dilihat pada tabel berikut ini. 
JIKAP PGSD: Jurnal Ilmiah Ilmu Kependidikan

Tabel 5. Data Statistik Hasil Belajar

\begin{tabular}{lcc}
\hline \multicolumn{1}{c}{ Data Statistik } & Siklus I & Siklus II \\
\hline Rata-rata & 73,80 & 81,19 \\
\hline Skor Tertinggi & 89 & 92 \\
\hline Skor Terendah & 64 & 68 \\
\hline Jumlah Peserta didik & 23 & 23 \\
\hline Jumlah Peserta didik yang tuntas & 18 & 20 \\
\hline Jumlah Peserta didik yang tidak tuntas & 5 & 3 \\
\hline Persentase Ketuntasan Klasikal & $78 \%$ & $87 \%$ \\
\hline Standar Deviasi & 6,79 & 6,22 \\
\hline Rentang skor $\quad(80 \leq \mathrm{N}<90)$ & 0 & 24 \\
\hline Kategori Sangat tinggi $\quad(90 \leq \mathrm{N} \leq 100)$ & 4 & 12 \\
\hline Kategori Tinggi $\quad(70 \leq \mathrm{N}<80)$ & 17 & 9 \\
\hline Kategori Sedang $\quad(\mathrm{N}<70)$ & 2 & $4 \%$ \\
\hline Kategori Rendah $\quad 17 \%$ & $52 \%$ \\
\hline Persentase Kategori Sangat Tinggi & $74 \%$ & $40 \%$ \\
\hline Persentase Kategori Tinggi & $9 \%$ & $4 \%$ \\
\hline Persentase Kategori Sedang & & 1 \\
\hline Persentase Kategori Rendah & $0 \%$ & \\
\hline
\end{tabular}

Berdasarkan tabel 5. menunjukkan peningkatan hasil belajar IPA yang diperoleh peserta didik setiap siklusnya. Pada siklus I setelah dilakukan Tes Hasil Belajar 1 terhadap 23 orang peserta didik, terdapat 5 orang peserta didik yang tidak mencapai nilai KKM atau ketuntasan klasikal sebesar $78 \%$ dengan rata-rata skor perolehan hasil belajar mencapai 73,80.

Pada siklus II terjadi peningkatan rata-rata skor perolehan hasil belajar IPA sebesar 81,19 dengan persentase ketuntasan klasikal mencapai $85 \%$, pada siklus II masih terdapat 3 orang peserta didik yang belum mencapai nilai KKM. Berdasarkan tabel di atas menunjukkan terjadinya peningkatan terhadap skor perolehan hasil balajar IPA pada setiap siklusnya, meskipun terdapat 3 orang peserta didik yang tidak tuntas yang mungkin disebabkan karena kurangnya persiapan dalam menghadapi tes hasil belajar.

Berdasarkan analisis terhadap lembar jawaban tes mereka, tampak bahwa perolehan tes hasil belajar yang diperoleh pada setiap siklusnya terdapat kesulitan dalam mengerjakan butir soal yang memerlukan perhitungan matematis terutama operasional dasar matematika seperti penjumlahan, pengurangan, dan perkalian. Secara umum peningkatan skor hasil belajar IPA lebih jelasnya diperlihatkan pada gambar 3 berikut ini.

\section{Rata-rata skor perolehan}

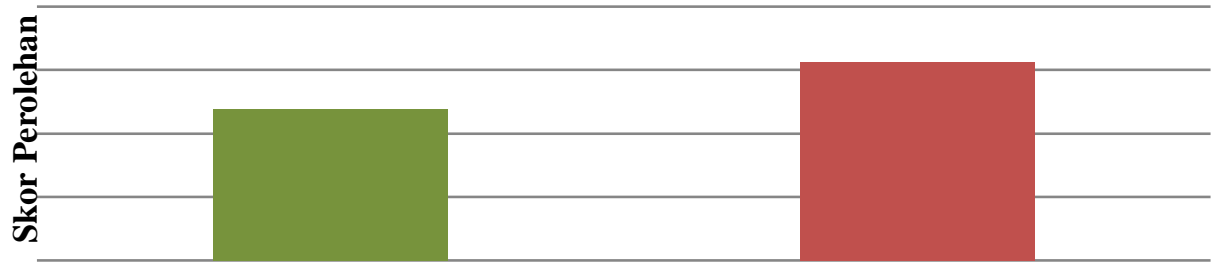

Gambar 3. Diagram rata-rata skor hasil belajar 
Dengan memotivasi dan membimbing kepada peserta didik yang tidak tuntas pada siklus I, baik dengan memberdayakan teman kelompok yang tuntas maupun dengan bimbingan khusus, berdampak terhadap hasil tes hasil belajar yang lebih baik pada siklus II. Berdasarkan analisa data hasil tes hasil belajar pada siklus II menunjukkan terjadinya peningkatan terhadap skor perolehan tes hasil belajar peserta didik, dimana ketuntasan pembelajaran telah mencapai kriteria ketuntasan minimal yang dipersyaratkan dan tercapainya ketuntasan secara klasikal $87 \%$.

\section{Data Hasil Pengamatan Keterlaksanaan Perangkat Pembelajaran}

Analisa data hasil pengamatan terhadap keterlaksanaan perangkat pembelajaran Inquiry Terbimbing pada siklus I dan siklus II menunjukkan bahwa seluruh kegiatan dalam pembelajaran Inquiry Terbimbing telah terlaksana seluruhnya. Pada siklus I diperoleh rata-rata keterlaksanaan (M) pada seluruh fase pembelajaran sebesar 1,86 dan pada siklus II diperoleh rata-rata keterlaksanaan (M) pada seluruh fase pembelajaran sebesar 1,92.

Tercapainya indikator keberhasilan dalam penelitian ini diperoleh setelah melalui beberapa tahap pada setiap siklusnya. Tindakan yang dilakukan untuk memperbaiki kondisi pembelajaran berdasarkan hasil pengamatan dan refleksi yang dilakukan selama siklus berjalan untuk dijadikan pertimbangan dalam menyusun dan merencanakan tindakan pada siklus selanjutnya.

Berdasarkan karakteristik kelas VIII3 pada semester genap tahun pelajaran 2018/2019 setelah diterapkannya pembelajaran Inquiry Terbimbing menunjukan terjadinya peningkatan terhadap motivasi dan hasil belajar IPA. Tindakan yang dilakukan dalam setiap siklus bertujuan untuk memperbaiki motivasi belajar yang berdampak terhadap penigkatan hasil belajar peserta didik kelas VIII-3.

\section{SIMPULAN DAN SARAN}

Berdasarkan hasil penelitian data baik secara deskriptif dan pembahasan hasil penelitian maka dikemukakan kesimpulan bahwa (1) Motivasi belajar peserta didik kelas VIII-3 yang dibelajarkan dengan model pembelajaran Inquiry Terbimbing mengalami peningkatan dan berada pada kategori tinggi. (2) Secara rata-rata hasil belajar belajar peserta didik kelas VIII-3 yang dibelajarkan dengan model pembelajaran Inquiry terbimbing meningkat dan berada pada kategori baik.

Adapaun saran yang dapat diberikan dalam penelitian ini adalah dalam pelaksanaan pembelajaran untuk menumbuhkan motivasi dan meningkatkan hasil belajar siswa penggunaan model Inquiry terbimbing dapat menjadi alternatif pilihan guru. Untuk itu, penguasaan dan pengembangan kemampuan guru dalam menggunakan model Inquiry terbimbing perlu ditingkatkan.

\section{DAFTAR RUJUKAN}

Am, S. (2011). Interaksi dan motivasi belajar mengajar. Jakarta: Raja Grafindo Persada.

Depdikbud. (1990). Kamus Besar Bahasa Indonesia. Jakarta: Balai Pustaka.

Gulo, W. (2008). Strategi Belajar Mengajar. PT Gerasindo. Jakarta.

Hanafiah. (2009). Konsep Strategi Pembelajaran. Bandung: Refika Aditama

Kementrian Pendidikan dan Kebuadayaan Indonesia. (2014). Buku Guru Ilmu Pengetahuan Alam SMP/MTS Kelas VII. Depdikbud. Jakarta

Purwanto, N. (2002). Psikologi Pendidikan. Bandung: Remaja Rosda karya.

Roestiyah. (2008). Metode Penelitian Kuantitatif Teori dan Aplikasi. Jakarta: Rajawali Press.

Slameto. (2003). Belajar dan Faktor yang Mempengaruhinya. Jakarta: PT. Asdi Maha Satya.

Sanjaya, W. (2010). Strategi Pembelajaran Berorentasi Standar Proses Pendidikan. Jakarta: Kencana Prenada Media Group. 
JIKAP PGSD: Jurnal Ilmiah Ilmu Kependidikan

Sofyan, Ahmad, dkk. (2010). Evaluasi Pembelajaran IPA Berbasis Kompetensi. Jakarta: UIN Jakarta Press.

Sugiyono. (2010). Statistika untuk Penelitian. Bandung: Alfabeta

Uno. (2009). Teori Motivasi dan Pengukurannya. Jakarta: PT. Bumi Aksara 